
\title{
R Research Soure \\ Optimization of Nutrient Parameters Influencing Oil Palm Seedling Growth in Soil Amended with Fly Ash and Sludge
}

James Okuo ( $\sim$ james.okuo@uniben.edu )

University of Benin, Benin City

lyayi Osa-Iguehide

University of Benin, Benin City

Bala Anegbe

Federal University Oye Ekiti

Babalola Bolanle

Federal University Oye Ekiti

\section{Research Article}

Keywords: Palm Oil Mill Sludge, Oil PalmFlyash, Stabilization, Amendment, Optimization

Posted Date: July 8th, 2021

DOI: https://doi.org/10.21203/rs.3.rs-629914/v1

License: (9) This work is licensed under a Creative Commons Attribution 4.0 International License.

Read Full License 
OPTIMIZATION OF NUTRIENT PARAMETERS INFLUENCING OIL PALM

SEEDLING GROWTH IN SOIL AMENDED WITH FLYASH AND SLUDGE

\author{
James M. Okuo ${ }^{\mathrm{a}}$,IyayiOsa-Iguehide ${ }^{\mathrm{a}}$, BalaAnegbe ${ }^{\mathrm{b}}$ and Babalola M.Bolanle ${ }^{\mathrm{b}}$
}

${ }^{a}$ Environmental Analytical Research Laboratory, Department of Chemistry, University

of Benin, Benin City. james.okuo@uniben.edu, gentleiyayi@yahoo.com

bDepartment of Industrial Chemistry, Federal University Oye-Ekiti, Ekiti State.

balaanegbe@yahoo.com, bolanle.babalola@fuoye.edu.ng

Corresponding Author:james.okuo@uniben.edu

Environmental Analytical Research Laboratory, Department of Chemistry, University

of Benin, Benin City

\begin{abstract}
The efficient use of organic fertilisers as a source of nutrient has been a concern in the world oilpalm production. The large amount of Palm Oil Mill Sludge (POMS) and Fly Ash (FA) produced in palm oil industries can effectively be utilized as organic fertilizers and so minimize the amount of waste dispose to the environment. This study is aimed at optimizing the nutrient parameters influencing oil palm seedling growth in soil amended with FA and POMS. The nutrient parameters were optimized using Response Surface Methodology (RSM). The optimization results showed that an increase in the mass of FA and a decrease in the mass of POMS result in a decrease in the growth response of the oil palm seedlings. The responses were best with increase in the mass of POMS and a decrease in the mass of FA. Therefore an indirect relationship exists between the masses of FA and POMS. An empirical quadratic polynomial model was developed to relate the interaction of the POMS and FA. The strong linear correlation between the observed and predicted responses showed that the model reasonably predicted the
\end{abstract}


process using a quadratic polynomial. The maximum plant height of $70.4 \mathrm{~cm}$ at $15 \%$ soil amendment was obtained at a mass of $1.46 \mathrm{~kg}$ FA and $8.54 \mathrm{~kg}$ POMS for the 180 days planting period. Results from this study showed that co application of FA and POMS can be very effective at a maximum of $14.6 \% \mathrm{FA}$ and minimum of $85.4 \%$ POMS by mass.

Keywords:Palm Oil Mill Sludge, Oil PalmFlyash, Stabilization, Amendment, Optimization

\subsection{INTRODUCTION}

Organic fertilizers are used to improve soil fertility in a productive state. Research has shown that fertilizer additionscan improve the content of organic matter that is present in the soil, thereby leading to improved fertilizer efficiency (Negassaet al. 2005). In many developing countries, the utilization of inorganic fertilizer is limited due to its high purchasing cost (Kassie et al. 2009; Dercon and Christiaensen, 2011), whereas only a small number of organic fertilizers are applied to their croplands despite the associatedbenefits(Baudronet al. 2014; Valbuenaet al. 2015).

The production of oil palm in Nigeria has risen tremendously from about eight million tonnes in 1990 to about nine million tonnes in 2001 (Food and Agricultural Organisation, 2002) and there has been a tremendous increase from 2001 till date. No doubt Edo State is one of the highest producers of palm oil in Nigeria.

About $43-45 \%$ of the entire production process is in the form of waste which is either solid waste or liquid waste. The solid wastes include empty fruit bunch (EFB), palm press fiber (PPF), chaff and palm kernel shell (PKS) (Ohimain and Izah, 2013, 2014, Ohimainet al. 2013; Rupaniet al. 2010). These solid wastes are burned as fuel in the boiler of palm oil mill at a temperature of about $450-600^{\circ} \mathrm{C}$ in the generation of energy for utilization in palm oil mill. Generally, after 
combustion, about $15 \%$ by weight of solid waste in the form of ash is produced. The ash produced is of two types which include fly ash and bottom ash.

The accumulation of these wastes is a continuous process as the production increases overtime. So there is need to put all effort in converting the waste into products (such as organic fertilizer and animal feed) that will be of economic importance to the palm oil industry.

Recycling and applying fly ash and sludge for agriculture purpose have many benefits which have been proven by various studies.

Keshet al. (2003) stated that FA serve as a repository of soil nutirent which helps to recover and improve soil properties from alkaline and saline soils. FA amended soils influence all of the soil's physical and chemical characteristics (electric conducting (EC) and particle size distributions) (Pathanet al. 2003; Singh et al. 2011).Singh et al. (2010) reported significant improvements in soil-based nutrient levels (e.g. $\mathrm{Na}, \mathrm{K}, \mathrm{Ca}, \mathrm{Mg}$, and $\mathrm{Fe}$ ) while Surridgeet al. (2009) have it thatFA has a liming effect on soils which enhances the mobility of calcium or hydroxide ion, enriching growth of bacteria.Devagiet al.(2016), revealed that POMS application can lead to a significant increase of $\mathrm{Mn}, \mathrm{Ni}$ and $\mathrm{Fe}$ in water spinach, which are parallel with increasing amount of POMS.

There is high competition of the Palm Oil Wastes for fuel and animal feeds and only small amounts of these wastes are retained in the soil. In addition, some of these wastes are discharged indiscriminately into the environment and thereby polluting the environment. Meanwhile, because these wastes are biodegradable they could serve as alternative source to soil amendment. The objectives of this study is to optimize the nutrient parameters influencing oil palm seedlings growth on soils amended with FA and POMS using Response Surface Methodology (RSM) and using a developed empirical quadratic polynomial model to relate the interaction of the POMS 
and FA and thus be able to predict the response of the oil palm seedlings to the different amendments. 


\subsection{MATERIALS AND METHODS}

\subsubsection{Sample Collection and Preparation}

Soil samples, FA and POMS were collected from Okomuvillage in Ovia South Local Government Area of Edo State. The soil samples were collected $0-30 \mathrm{~cm}$ at about $2 \mathrm{~km}$ from Okomu oil palm industry. The soil samples were air dried for a period of two weeks before beingcrushed in porcelain mortal and sieved through $2 \mathrm{~mm}$ sieve. The air-dried sieved soil samples were stored in air tight polythene bags and labeled prior to analysis. The fly ash was also sieved through a $2 \mathrm{~mm}$ sieve to obtain fine sample. The sludge sample was stabilized for a period of 100 days as described by Osa-Iguehide et al. (2021). The prepared fly ash and stabilized sludge were separately and co-applied to the soil at different rate (i.e from $2-15 \%$ ).

Plant samples were analyze according to USEPA guidelines.

\subsubsection{Physicochemical Characterization}

The physicochemical properties of the soil, fly ash and stabilized sludge at day 0 and 100 days were determined before and after amendment using standard methods. The $\mathrm{pH}$ and Particle size analysis was determined by the method described by Vogel, (2008). Total nitrogen and phosphorus was determined by Kjeldahl method described by Motsara and Roy, (2008). Flame photometric method was used for the analysis of $\mathrm{K}$ and $\mathrm{Na}$ while $\mathrm{Mg}$, $\mathrm{Ca}$ and heavy metals were analyzed using atomic absorption spectrophotometric method described by Wuanaet al.(2008) The plants biometrics were done 180 days after planting.

\subsection{Nutrient Parameters Optimization using Response Surface Methodology (RSM)}

\subsubsection{Central CompositeDesign (CCD) of Soil Amendment Process}

RSM was used to assess the influence of various process parameters to maximize plant height of oil palm seedlings. The experimental design for this reaction was carried out by employing a full 
factorial rotatable central composite design (RCCD) for two factors with replicates at the centre point, and star points were used in the investigation by the statistical software package Designexpert $^{\circledR}$ (version 8.0.6; stat-ease, Inc., Minneapolis, USA). The variables used were mass of FA $(A)$ and mass of POMS (B) each at alpha (-1) and alpha (+1) coded levels. The actual levels of the variables for CCD experiments were selected based on the initial levels as the center points. A total of 13 experimental trials that included 4 trials for factorial design, 4 trials for axial points (two for each variable) and 5 trials for replication of the central points were performed. The response of the amendment process is plant height incentimeter $(\mathrm{cm})$. Table 1 shows the CCD experimental range of values for the process variables considered for the soil amendment process.

Table 1: CCD Experimental Conditions for the Soil Amendment Process

\begin{tabular}{lllll}
\hline $\begin{array}{l}\text { Independent } \\
\text { variable }\end{array}$ & Unit & Symbol & $\begin{array}{l}\text { Levels } \\
\mathbf{- 1}\end{array}$ & $\mathbf{+ 1}$ \\
\hline Mass of FA & $\mathrm{Kg}$ & $\mathrm{A}$ & 0 & 10 \\
Mass of POMS & $\mathrm{Kg}$ & $\mathrm{B}$ & 0 & 10 \\
\hline
\end{tabular}

\subsection{Statistical Analysis}

The experimental data were analyzed according to the response surface regression procedure to fit the second-order polynomial equation in which the level of significance (p-value) of all coefficients was $<0.05$. Based on experimental data shown in Table 1, the regression coefficient was determined by the statistical software package Design-expert ${ }^{\circledR}$ (version 8.0.6; stat-ease, Inc., Minneapolis, USA) to predict the process response as a function of independent variables and their interactions were used to understand the system behaviour. The coded values of the process parameters were determined by equation 1 .

$$
\mathrm{x}_{\mathrm{i}}=\left(\mathrm{X}_{\mathrm{i}}-\mathrm{X}_{\mathrm{o}}\right) / \Delta \mathrm{x}
$$


where $x_{i}-$ coded value of the ith variable, $X_{i}-$ uncoded value of the ith test variable and $X_{o}-$ uncoded value of the ith test variable at centre point. The mathematical relationship between the process variables and response was calculated by the quadratic polynomial expression in equation 2 .

$Y=\beta_{0}+\sum_{i=1}^{n} \beta_{i} x_{i}+\sum_{i=1}^{n} \beta_{i i} x_{i}^{2}+\sum_{i=1}^{n} \sum_{j>1}^{n} \beta_{i j} x_{i} x_{j}$

where $Y$ is the response, i.e. the plant height $(\mathrm{cm}), X_{\mathrm{i}}$ and $X_{\mathrm{j}}$ represent the independent variables, $\beta_{0}$ is constant, $\beta_{\mathrm{i}}$ is linear term coefficient, $\beta_{\mathrm{ii}}$ is the quadratic term coefficient, $\beta_{\mathrm{ij}}$ is cross-term coefficient and ' $n$ ' is the number of process variables studied and optimized during the study. ANOVA was carried out to estimate the effects of process variables and their possible interaction effects on the maximum plant height in the response surface regression procedure. The goodness and best fit of the model was evaluated by a regression coefficient $R^{2}$. The response surface and contour plots are obtained using the fitted quadratic polynomial equation generated from regression analysis by keeping one of the independent variables at central value (0) and varying the other.

\subsection{Pot Experiments}

A greenhouse pot experiment was adopted in this research. Sprouted palm seedlings obtained from Nigeria Institute for Oil Palm Research (NIFOR) were carefully sown in blackcylindrical polythene bags, each containing $2 \mathrm{~kg}$ soil mixture (soil + FA + POMS as suggested by RSM). Prior to planting, the soil mixture was stabilized for a period of two weeks while watering once a day with about $200 \mathrm{~cm}^{3}$ of water. One sprouted palm seedling was planted per pot and each experiment was performed in triplicate. Surface irrigation was done with borehole water based on the water holding capacity of the soil once a day for the 180 days planting period while plant analysis was done 60, 120 and 180 days after planting (Osa-Iguehie et al. 2021). 


\subsection{RESULTS AND DISCUSSION}

Table 2: Physicochemical Parameters of the FA, POMS at Different Stabilization Days and

Soil before Amendment

\begin{tabular}{lllllllllll}
\hline & $\mathrm{pH}$ & $\begin{array}{l}\mathrm{P} \\
(\%)\end{array}$ & $\begin{array}{l}\mathrm{N} \\
(\%)\end{array}$ & $\begin{array}{l}\text { TOC } \\
(\%)\end{array}$ & $\begin{array}{l}\text { TOM } \\
(\%)\end{array}$ & $\begin{array}{l}\mathrm{C}: \mathrm{N} \\
\text { Ratio }\end{array}$ & $\begin{array}{l}\mathrm{Na} \\
(\mathrm{meq} / 100 \mathrm{~g})\end{array}$ & $\begin{array}{l}\mathrm{K} \\
(\mathrm{meq} / 100 \mathrm{~g})\end{array}$ & $\begin{array}{l}\mathrm{Ca} \\
(\mathrm{meq} / 100 \mathrm{~g})\end{array}$ & $\begin{array}{l}\mathrm{Mg} \\
(\mathrm{meq} / 100 \mathrm{~g})\end{array}$ \\
\hline FA & 10.92 & 0.105 & 0.08 & 0.69 & 1.19 & 5.77 & 3.55 & 1.68 & 12.75 & 6.88 \\
POMS $_{0}$ & 4.07 & 0.136 & 0.19 & 8.49 & 14.61 & 44.71 & 0.52 & 0.36 & 6.23 & 4.13 \\
POMS $_{100}$ & 5.21 & 0.364 & 0.51 & 6.59 & 11.33 & 12.92 & 0.59 & 0.38 & 7.02 & 4.28 \\
SOIL & 7.70 & 0.013 & 0.09 & 1.25 & 2.15 & 13.89 & 0.08 & 0.06 & 0.74 & 0.43 \\
\hline
\end{tabular}

Table 3: Particle Size Analysis of the Soil (\%)

\begin{tabular}{lllll}
\hline & & & & \\
& PARTICLE SIZE & & \\
& TOTAL & TOTAL & TOTAL & \\
& SAND & SILT & CLAY & TEXTURE \\
\hline SOIL & 85 & 6 & 9 & LOAM \\
\hline
\end{tabular}

Table 2 shows the physicochemical parameters of the soil, fly ash and stabilized sludge. The $\mathrm{pH}$ of the soil was 7.70 which is slightly above normal $\mathrm{pH}$ for plant growth, even though most soils have $\mathrm{pH}$ values between 3.5 and 10 (Queensland Department of Environment and Heritage Protection, 2016). Soil pH is one of the important parameters in soil analysis as it affects most chemical processes. It specifically affects the availability of nutrients to plant by contributing significantly to the chemical forms of the different nutrients thereby affecting the chemical reactions which these nutrients undergo in soil. The fly ash was alkaline with a $\mathrm{pH}$ of $10.92 ; \mathrm{pH}$ value of fly ash has close correlation with its $\mathrm{CaO}$ content. High $\mathrm{CaO}$ content in fly ash results in higher $\mathrm{pH}$ value (Antoni, 2016).The high $\mathrm{pH}$ of the FA makes it very suitable as a liming agent for acidic soil 
The optimum soil pH range for most plants is between 5.5 and 7.5 (Queensland Department of Environment and Heritage Protection, 2016). This is assumed to be the normal $\mathrm{pH}$ range for ordinary soils that favour plant and microorganisms. However, many plants have adapted to thrive at $\mathrm{pH}$ values outside this range. The particle size analysis (table 3 ) of the soil shows that, the parent soil has a clay content of $9 \%$, silt $6 \%$ and sand $85 \%$ which makes the soil to be classified as loamy sand.

To study the individual and interactive effects of variables, a 3 point Rotated Central Composite Design (RCCD) was used for the 2 variables. The factorial point shows the values that are within the range of the coded value from the design of experiment as shown in Table 3.

Table 4: Standard Order of the Actual and Coded Values of the Optimized Parameters

\begin{tabular}{|c|c|c|c|c|c|}
\hline & \multirow{2}{*}{$\begin{array}{l}\text { Std } \\
\text { order }\end{array}$} & \multicolumn{2}{|c|}{ Coded values } & \multicolumn{2}{|c|}{ Actual values } \\
\hline & & $\bar{A}$ & $\mathrm{~B}$ & $\begin{array}{l}\mathrm{FA} \\
(\mathrm{kg}) \\
\end{array}$ & POMS (kg) \\
\hline \multirow{4}{*}{ Factorial Point } & 1 & -1 & -1 & 1.46 & 1.46 \\
\hline & 2 & 1 & -1 & 8.54 & 1.46 \\
\hline & 3 & -1 & 1 & 1.46 & 8.54 \\
\hline & 4 & 1 & 1 & 8.54 & 8.54 \\
\hline \multirow{4}{*}{ Axial Point } & 5 & -1.41 & 0 & 0.00 & 5.00 \\
\hline & 6 & 1.41 & 0 & 10.00 & 5.00 \\
\hline & 7 & 0 & -1.41 & 5.00 & 0.00 \\
\hline & 8 & 0 & 1.41 & 5.00 & 10.00 \\
\hline \multirow{5}{*}{ CentrePoint } & 9 & 0 & 0 & 5.00 & 5.00 \\
\hline & 10 & 0 & 0 & 5.00 & 5.00 \\
\hline & 11 & 0 & 0 & 5.00 & 5.00 \\
\hline & 12 & 0 & 0 & 5.00 & 5.00 \\
\hline & 13 & 0 & 0 & 5.00 & 5.00 \\
\hline
\end{tabular}

To study the individual and interactive effects of variables, a 3 point Rotated Central Composite Design (RCCD) was used for the 2 variables. The factorial point shows the values that are within the range of the coded value from the design of experiment as shown in Table 4.The axial point 
shows the values that are outside the range of the coded value from experimental design. The centre points show the experimental runs where the values are set halfway between the highest and lowest value. The actual values for each point shows the masses of the FA and POMS that was uniformly mixed for the amendment.

Orders $1,4,9-13$ showed the same growth pattern. The similar growth pattern showed by these orders could be attributed to the 50/50 ratio in which these orders were mixed. Order 1 had an FA mass of $1.46 \mathrm{~kg}$ and POMS mass of $1.46 \mathrm{~kg}$, order 4 had a FA mass of $8.54 \mathrm{~kg}$ and POMS mass of 8.54 . Order $9-13$ had FA mass of $5 \mathrm{~kg}$ and POMS mass of $5 \mathrm{~kg}$. These orders were used to determine the variation in the optimization process (Table 5).

Table 5: Growth Analysis of Oil Palm Seedlings (cm)

\begin{tabular}{|c|c|c|c|c|c|c|c|c|c|c|c|c|}
\hline \multirow[b]{2}{*}{ Std Ordex } & \multicolumn{3}{|c|}{ RESPONSE $1(\mathrm{~A})$} & \multicolumn{3}{|c|}{ RESPONSE 2 (B) } & \multicolumn{3}{|c|}{ RESPONSE 3 (C) } & \multicolumn{3}{|c|}{ RESPONSE4 (D } \\
\hline & 60 & 120 & 180 & 60 & 120 & 180 & 60 & 120 & 180 & 60 & 120 & 180 \\
\hline 1. & 25.3 & 35.7 & 47.9 & 32.1 & 41.2 & 52.1 & 23.8 & 40.8 & 54.2 & 24.2 & 37.2 & 46.5 \\
\hline 2. & 22.8 & 29.6 & 42.8 & 21.6 & 27.4 & 32.6 & 19.5 & 24.1 & 26.5 & 16.4 & 19.3 & 23.2 \\
\hline 3. & 28.9 & 42.4 & 57.8 & 37.6 & 51.3 & 61.3 & 29.7 & 58.1 & 64.7 & 27.1 & 58.4 & 70.4 \\
\hline 4. & 24.8 & 36.3 & 44.2 & 30.7 & 39.8 & 53.6 & 25.9 & 41.4 & 56.6 & 23.1 & 35.2 & 49.8 \\
\hline 5. & 29.5 & 47.5 & 57.3 & 38.4 & 52.8 & 59.8 & 28.5 & 54.4 & 63.6 & 25.9 & 56.8 & 69.8 \\
\hline 6. & 23.9 & 32.6 & 43.2 & 26.8 & 32.7 & 44.7 & 20.1 & 30.9 & 42.1 & 19.7 & 25.4 & 33.9 \\
\hline 7. & 22.4 & 29.4 & 35.7 & 19.2 & 21.0 & 27.6 & 15.6 & 18.5 & 22.1 & 11.3 & 14.7 & 19.8 \\
\hline 8. & 27.1 & 38.3 & 51.7 & 35.7 & 44.4 & 55.8 & 30.7 & 44.2 & 57.3 & 26.3 & 49.9 & 60.9 \\
\hline 9. & 25.1 & 34.7 & 46.2 & 31.4 & 40.1 & 50.7 & 23.7 & 41.4 & 53.2 & 24.2 & 35.2 & 47.6 \\
\hline 10. & 26.2 & 36.3 & 44.9 & 33.4 & 39.8 & 51.5 & 24.9 & 38.5 & 52.9 & 23.5 & 36.8 & 46.2 \\
\hline 11. & 25.8 & 33.9 & 48.4 & 32.6 & 40.8 & 51.9 & 24.2 & 39.7 & 54.5 & 23.9 & 37.4 & 45.7 \\
\hline 12. & 24.6 & 37.6 & 45.6 & 33.3 & 41.3 & 52.0 & 25.2 & 38.1 & 53.3 & 24.8 & 35.2 & 48.9 \\
\hline 13. & 25.7 & 36.5 & 46.9 & 30.9 & 39.8 & 50.8 & 23.9 & 37.7 & 53.9 & 23.8 & 35.8 & 47.1 \\
\hline
\end{tabular}

Response $\mathrm{A}=2 \%$ Amendment, Response $\mathrm{B}=5 \%$ Amendment, Response $\mathrm{C}=10 \%$

\section{Amendment, Response D = $15 \%$ Amendment}

During the First 60 days it was observed that the plant height for these orders increased from 2 $5 \%$ amendment and then decreased from $10-15 \%$ amendment, this pattern continued to120 days after planting. But after 180 days of planting there was a gradual increase in the plant height 
from $2-10 \%$ amendment and a decrease in $15 \%$ amendment. This growth pattern can be attributed to the fact that the FA was more dominant in affecting the plant height due to the slight increase in the $\mathrm{pH}$ of these orders as the rate of amendment increased and as such the higher $\mathrm{pH}$ led to the slower growth rate during the first 120 days of planting. However after 180 days of planting there was a slight change in the growth pattern as $10 \%$ amendment was observed to have led to increase in the plant height as compared to the growth during 120 days of planting. The increase in plant height at $10 \%$ amendment could be attributed to decomposition of the organic matter making nutrients available for plant uptake. But this increase did not extend to the plant height at $15 \%$ amendment which may be due to the fact that the higher $\mathrm{pH}$ could not have made the nutrient readily available for the plant and as such a decrease in the plant height in the $15 \%$ amendment.

Orders 2 and 7 showed similar growth pattern, the growth pattern shown by these orders could be attributed to the higher percentage of FA as compared with the percentage of the POMS. Order 2 has a FA mass of $8.54 \mathrm{~kg}$ and POMS mass of $1.46 \mathrm{~kg}$; order 7 has FA mass of $5 \mathrm{~kg}$ and a POMS mass of $0 \mathrm{~kg}$. This corresponds to $85.4 \%$ and $100 \%$ of FAin the composite mixture for orders 2 and 7 respectively.

During this first 60 days of planting, the height of the plants were found to decrease as the rate of amendment with order 2 and 7 increase from $2-15 \%$ and this pattern was also observed for 120 and 180 days after planting. This decrease in height of plant with increase in percentage amendment of order 2 and 7 could be attributed to the increase in $\mathrm{pH}$ of the soil as the rate of amendment increases. The high $\mathrm{pH}$ led to the low availability of the nutrient as observed in the nutrient analysis of the plantshown inTables6 - 8. Study has shown that there is restriction in plant growth in strongly alkaline $\mathrm{pH}(\mathrm{pH} 8.5-9)($ United State Department of Agriculture, 2000) 
due to poor aeration, depletion of plant-available water leading to the soils becoming hard and cloddy. There was also a gradual decrease in concentration of nitrogen and phosphorus as the rate of amendment increased with orders 2 and 7. The least plant height of $19.8 \mathrm{~cm}$ was observed for $15 \%$ order 7 with FA mass of $5.00 \mathrm{~kg}$ and $0.00 \mathrm{~kg}$ POMS.

The plant height of Orders 3, 5, and 8 increased from $2-5 \%$ amendment and then decreased from $10-15 \%$ amendment in the first 60 days of planting. This could be attributed to slow decomposition of the organic matter which increased as the rate of amendment increased from 10 $-15 \%$ and as such mineralization was slower in these amended samples. This led to the lower nutrient availability of these soils when compared with the 2 and $5 \%$ amendment which has better growth performance due to lower organic matter and as such faster rate of decomposition within the first 60 days. There was a change in this pattern 120 days after planting.

The highest plant height of $58.4 \mathrm{~cm}$ was recorded in $15 \%$ order 3 . There was a slight increase in the plant height as the rate of amendment increase from $2-15 \%$ with order 3 and 5 which showed that after 120 days of planting the organic matter has decomposed to an appreciable extent and hence the nutrient is now available for plant uptake. This was also evidence in the nutrient analysis of the plant (Tables 6 - 8). However after 180 days of planting, the plant heights were observed to increase tremendously with increase in the rate of amendment. This showed that the rate of mineralization increased with the decomposition of organic matter leading to greater availability of nutrient for the plants and hence the better growth performance with increase in rate of amendment.

The optimum plant height of $70.4 \mathrm{~cm}$ was observed for $15 \%$ order 3 with FA mass of $1.46 \mathrm{~kg}$ and POMS mass of $8.54 \mathrm{~kg}$.

Presented in Tables $6-8$ is the nutrient analysis of the plant during the planting period. 
Table 6:Nutrient Analysis (\%) of Plant 60 Days after Planting

\begin{tabular}{|c|c|c|c|c|c|}
\hline Std order & Parameters & $2 \%$ & $5 \%$ & $10 \%$ & $15 \%$ \\
\hline \multirow[t]{3}{*}{1} & $\mathrm{~N}$ & 0.177 & 0.184 & 0.168 & 0.160 \\
\hline & $\mathrm{P}$ & 0.101 & 0.107 & 0.096 & 0.091 \\
\hline & $\mathrm{K}$ & 0.017 & 0.021 & 0.027 & 0.031 \\
\hline \multirow[t]{3}{*}{2} & $\mathrm{~N}$ & 0.151 & 0.143 & 0.132 & 0.120 \\
\hline & $\mathrm{P}$ & 0.092 & 0.086 & 0.081 & 0.058 \\
\hline & $\mathrm{K}$ & 0.038 & 0.044 & 0.048 & 0.057 \\
\hline \multirow[t]{3}{*}{3} & $\mathrm{~N}$ & 0.198 & 0.217 & 0.208 & 0.193 \\
\hline & $\mathrm{P}$ & 0.118 & 0.122 & 0.129 & 0.132 \\
\hline & $\mathrm{K}$ & 0.008 & 0.013 & 0.021 & 0.026 \\
\hline \multirow[t]{3}{*}{4} & $\mathbf{N}$ & 0.169 & 0.178 & 0.162 & 0.157 \\
\hline & $\mathrm{P}$ & 0.096 & 0.107 & 0.098 & 0.084 \\
\hline & $\mathrm{K}$ & 0.015 & 0.022 & 0.029 & 0.034 \\
\hline \multirow[t]{3}{*}{5} & $\mathrm{~N}$ & 0.203 & 0.219 & 0.196 & 0.186 \\
\hline & $\mathrm{P}$ & 0.132 & 0.139 & 0.135 & 0.128 \\
\hline & $\mathrm{K}$ & 0.005 & 0.012 & 0.018 & 0.023 \\
\hline \multirow[t]{3}{*}{6} & $\mathrm{~N}$ & 0.147 & 0.152 & 0.149 & 0.134 \\
\hline & $\mathrm{P}$ & 0.097 & 0.109 & 0.094 & 0.090 \\
\hline & $\mathrm{K}$ & 0.029 & 0.031 & 0.038 & 0.043 \\
\hline \multirow[t]{3}{*}{7} & $\mathrm{~N}$ & 0.117 & 0.101 & 0.092 & 0.077 \\
\hline & $\mathrm{P}$ & 0.086 & 0.081 & 0.075 & 0.068 \\
\hline & $\mathrm{K}$ & 0.041 & 0.049 & 0.056 & 0.072 \\
\hline \multirow[t]{3}{*}{8} & $\mathrm{~N}$ & 0.152 & 0.165 & 0.161 & 0.148 \\
\hline & $\mathrm{P}$ & 0.105 & 0.117 & 0.109 & 0.094 \\
\hline & $\mathrm{K}$ & 0.028 & 0.032 & 0.038 & 0.045 \\
\hline \multirow[t]{3}{*}{9} & $\mathrm{~N}$ & 0.181 & 0.187 & 0.173 & 0.169 \\
\hline & $\mathrm{P}$ & 0.103 & 0.109 & 0.101 & 0.096 \\
\hline & $\mathrm{K}$ & 0.015 & 0.027 & 0.032 & 0.039 \\
\hline \multirow[t]{3}{*}{10} & $\mathrm{~N}$ & 0.176 & 0.182 & 0.177 & 0.174 \\
\hline & $\mathrm{P}$ & 0.098 & 0.109 & 0.091 & 0.084 \\
\hline & $\mathrm{K}$ & 0.026 & 0.029 & 0.037 & 0.042 \\
\hline \multirow[t]{3}{*}{11} & $\mathrm{~N}$ & 0.182 & 0.195 & 0.18 & 0.176 \\
\hline & $\mathrm{P}$ & 0.103 & 0.119 & 0.097 & 0.095 \\
\hline & $\mathrm{K}$ & 0.016 & 0.022 & 0.029 & 0.037 \\
\hline \multirow[t]{3}{*}{12} & $\mathbf{N}$ & 0.185 & 0.199 & 0.178 & 0.172 \\
\hline & $\mathrm{P}$ & 0.107 & 0.118 & 0.103 & 0.094 \\
\hline & $\mathrm{K}$ & 0.015 & 0.024 & 0.031 & 0.035 \\
\hline \multirow[t]{3}{*}{13} & $\mathbf{N}$ & 0.178 & 0.186 & 0.18 & 0.175 \\
\hline & $\mathrm{P}$ & 0.104 & 0.11 & 0.096 & 0.088 \\
\hline & $\mathrm{K}$ & 0.014 & 0.021 & 0.029 & 0.033 \\
\hline
\end{tabular}


Table 7:Nutrient Analysis (\%) of Plant 120 Days after Planting

\begin{tabular}{|c|c|c|c|c|c|}
\hline Std order & Parameters & $2 \%$ & $5 \%$ & $10 \%$ & $15 \%$ \\
\hline \multirow[t]{3}{*}{1} & $\mathrm{~N}$ & 0.182 & 0.204 & 0.198 & 0.187 \\
\hline & $\mathrm{P}$ & 0.124 & 0.135 & 0.134 & 0.13 \\
\hline & K & 0.024 & 0.033 & 0.038 & 0.045 \\
\hline \multirow[t]{3}{*}{2} & $\mathrm{~N}$ & 0.169 & 0.161 & 0.155 & 0.127 \\
\hline & $\mathrm{P}$ & 0.103 & 0.095 & 0.087 & 0.066 \\
\hline & $\mathrm{K}$ & 0.046 & 0.056 & 0.064 & 0.069 \\
\hline \multirow[t]{3}{*}{3} & $\mathrm{~N}$ & 0.221 & 0.239 & 0.251 & 0.249 \\
\hline & $\mathrm{P}$ & 0.138 & 0.153 & 0.178 & 0.182 \\
\hline & $\mathrm{K}$ & 0.012 & 0.019 & 0.026 & 0.032 \\
\hline \multirow[t]{3}{*}{4} & $\mathrm{~N}$ & 0.188 & 0.203 & 0.214 & 0.182 \\
\hline & $\mathrm{P}$ & 0.131 & 0.151 & 0.158 & 0.146 \\
\hline & K & 0.021 & 0.029 & 0.035 & 0.047 \\
\hline \multirow[t]{3}{*}{5} & $\mathrm{~N}$ & 0.224 & 0.246 & 0.253 & 0.259 \\
\hline & $\mathrm{P}$ & 0.142 & 0.157 & 0.171 & 0.179 \\
\hline & K & 0.009 & 0.014 & 0.022 & 0.034 \\
\hline \multirow[t]{3}{*}{6} & $\mathrm{~N}$ & 0.163 & 0.172 & 0.158 & 0.152 \\
\hline & $\mathrm{P}$ & 0.118 & 0.125 & 0.121 & 0.113 \\
\hline & K & 0.037 & 0.043 & 0.054 & 0.061 \\
\hline \multirow[t]{3}{*}{7} & $\mathrm{~N}$ & 0.152 & 0.121 & 0.115 & 0.087 \\
\hline & $\mathrm{P}$ & 0.107 & 0.096 & 0.093 & 0.081 \\
\hline & K & 0.054 & 0.061 & 0.068 & 0.113 \\
\hline \multirow[t]{3}{*}{8} & $\mathrm{~N}$ & 0.178 & 0.197 & 0.218 & 0.203 \\
\hline & $\mathrm{P}$ & 0.122 & 0.131 & 0.157 & 0.161 \\
\hline & $\mathrm{K}$ & 0.039 & 0.043 & 0.049 & 0.059 \\
\hline \multirow[t]{3}{*}{9} & $\mathbf{N}$ & 0.193 & 0.214 & 0.203 & 0.195 \\
\hline & $\mathrm{P}$ & 0.128 & 0.139 & 0.136 & 0.123 \\
\hline & $\mathrm{K}$ & 0.023 & 0.032 & 0.038 & 0.047 \\
\hline \multirow[t]{3}{*}{10} & $\mathrm{~N}$ & 0.189 & 0.208 & 0.212 & 0.206 \\
\hline & $\mathrm{P}$ & 0.125 & 0.137 & 0.141 & 0.116 \\
\hline & $\mathrm{K}$ & 0.031 & 0.035 & 0.042 & 0.053 \\
\hline \multirow[t]{3}{*}{11} & $\mathrm{~N}$ & 0.192 & 0.208 & 0.199 & 0.189 \\
\hline & $\mathrm{P}$ & 0.128 & 0.133 & 0.124 & 0.116 \\
\hline & $\mathrm{K}$ & 0.025 & 0.034 & 0.041 & 0.048 \\
\hline \multirow[t]{3}{*}{12} & $\mathrm{~N}$ & 0.201 & 0.207 & 0.191 & 0.187 \\
\hline & $\mathrm{P}$ & 0.123 & 0.129 & 0.122 & 0.114 \\
\hline & K & 0.021 & 0.029 & 0.037 & 0.046 \\
\hline \multirow[t]{3}{*}{13} & $\mathrm{~N}$ & 0.196 & 0.205 & 0.197 & 0.191 \\
\hline & $\mathrm{P}$ & 0.124 & 0.133 & 0.123 & 0.107 \\
\hline & $\mathrm{K}$ & 0.019 & 0.029 & 0.042 & 0.055 \\
\hline
\end{tabular}


Table 8:Nutrient Analysis (\%) of Plant 180 Days after Planting

\begin{tabular}{|c|c|c|c|c|c|}
\hline Std order & Parameters & $2 \%$ & $5 \%$ & $10 \%$ & $15 \%$ \\
\hline \multirow[t]{3}{*}{1} & $\mathrm{~N}$ & 0.198 & 0.238 & 0.241 & 0.223 \\
\hline & $\mathrm{P}$ & 0.136 & 0.161 & 0.178 & 0.144 \\
\hline & $\mathrm{K}$ & 0.036 & 0.041 & 0.049 & 0.058 \\
\hline \multirow[t]{3}{*}{2} & $\mathrm{~N}$ & 0.185 & 0.172 & 0.145 & 0.129 \\
\hline & $\mathrm{P}$ & 0.122 & 0.106 & 0.093 & 0.067 \\
\hline & $\mathrm{K}$ & 0.073 & 0.089 & 0.098 & 0.106 \\
\hline \multirow[t]{3}{*}{3} & $\mathrm{~N}$ & 0.258 & 0.279 & 0.303 & 0.316 \\
\hline & $\mathrm{P}$ & 0.196 & 0.217 & 0.234 & 0.257 \\
\hline & $\mathrm{K}$ & 0.021 & 0.028 & 0.032 & 0.041 \\
\hline \multirow[t]{3}{*}{4} & $\mathrm{~N}$ & 0.192 & 0.235 & 0.251 & 0.236 \\
\hline & $\mathrm{P}$ & 0.178 & 0.188 & 0.21 & 0.154 \\
\hline & $\mathrm{K}$ & 0.037 & 0.049 & 0.051 & 0.56 \\
\hline \multirow[t]{3}{*}{5} & $\mathrm{~N}$ & 0.249 & 0.262 & 0.294 & 0.307 \\
\hline & $\mathrm{P}$ & 0.185 & 0.189 & 0.225 & 0.233 \\
\hline & $\mathrm{K}$ & 0.015 & 0.024 & 0.029 & 0.037 \\
\hline \multirow[t]{3}{*}{6} & $\mathrm{~N}$ & 0.181 & 0.201 & 0.178 & 0.169 \\
\hline & $\mathrm{P}$ & 0.174 & 0.183 & 0.169 & 0.115 \\
\hline & $\mathrm{K}$ & 0.061 & 0.065 & 0.073 & 0.098 \\
\hline \multirow[t]{3}{*}{7} & $\mathrm{~N}$ & 0.169 & 0.134 & 0.128 & 0.094 \\
\hline & $\mathrm{P}$ & 0.134 & 0.112 & 0.104 & 0.081 \\
\hline & K & 0.087 & 0.098 & 0.105 & 0.113 \\
\hline \multirow[t]{3}{*}{8} & $\mathrm{~N}$ & 0.227 & 0.243 & 0.254 & 0.272 \\
\hline & $\mathrm{P}$ & 0.143 & 0.162 & 0.175 & 0.189 \\
\hline & $\mathrm{K}$ & 0.058 & 0.064 & 0.079 & 0.084 \\
\hline \multirow[t]{3}{*}{9} & $\mathrm{~N}$ & 0.221 & 0.238 & 0.247 & 0.231 \\
\hline & $\mathrm{P}$ & 0.132 & 0.141 & 0.153 & 0.127 \\
\hline & $\mathrm{K}$ & 0.052 & 0.069 & 0.072 & 0.079 \\
\hline \multirow[t]{3}{*}{10} & $\mathrm{~N}$ & 0.214 & 0.248 & 0.257 & 0.229 \\
\hline & $\mathrm{P}$ & 0.139 & 0.147 & 0.158 & 0.124 \\
\hline & $\mathrm{K}$ & 0.056 & 0.066 & 0.069 & 0.074 \\
\hline \multirow[t]{3}{*}{11} & $\mathrm{~N}$ & 0.225 & 0.239 & 0.254 & 0.237 \\
\hline & $\mathrm{P}$ & 0.132 & 0.152 & 0.162 & 0.119 \\
\hline & $\mathrm{K}$ & 0.053 & 0.061 & 0.072 & 0.078 \\
\hline \multirow[t]{3}{*}{12} & $\mathrm{~N}$ & 0.209 & 0.231 & 0.257 & 0.231 \\
\hline & $\mathrm{P}$ & 0.137 & 0.147 & 0.152 & 0.123 \\
\hline & $\mathrm{K}$ & 0.051 & 0.063 & 0.068 & 0.076 \\
\hline \multirow[t]{3}{*}{13} & $\mathrm{~N}$ & 0.224 & 0.228 & 0.263 & 0.239 \\
\hline & $\mathrm{P}$ & 0.136 & 0.145 & 0.157 & 0.119 \\
\hline & $\mathrm{K}$ & 0.060 & 0.065 & 0.071 & 0.075 \\
\hline
\end{tabular}

Std Order: Standard order 
During the first 60 days, the level of nitrogen, phosphorus and potassium in the plant ranged from $0.077-0.219 \%, 0.058-0.137 \%$ and $0.023-0.077 \%$ respectively. Orders 3 and 5 showed more nitrogen and phosphorus absorption at 2 and $5 \%$ amendment. It was observed that the absorption of nitrogen and phosphorus increased from $2-5 \%$ amendment and then decreased gradually from $10-15 \%$ amendment. The decrease in the absorption of nutrient from $10-15 \%$ in orders 3 and 5 could be attributed to the high organic matter contents in the orders, this tend to temporarily immobilize these nutrients before the complete mineralization of the organic matter. The higher nutrients absorption at 2 and $5 \%$ of orders 3 and 5 can therefore be attributed to lower organic matter content which decomposed faster and the nutrients was readily release for plant uptake. The absorption of nutrients by the plant was also evident in the plant growth.

There was also a gradual decrease in concentration of nitrogen and phosphorus as the rate of amendment increased in orders 2 and 7. The decrease in absorption of these nutrients in these orders can be attributed to low concentration of these nutrients in FAbecause these orders have higher percentage of FA (85.4 and $100 \%$ for orders 2 and 7 respectively) and thus extremely high pH. Queensland Department of Environment and Heritage Protection (2017) reported that the optimum $\mathrm{pH}$ range for most plants is between 5.5 and 7.5. When $\mathrm{pH}$ exceeds this range nutrient availability tends to decrease.

After 120 days of planting the absorption of nutrients was similar to what was observed for the 60 days planting period, there was slight increase in the absorption of nutrient by the plants. The highest concentration of nitrogen and phosphorus were found in orders 3 and 5 while the lowest concentration nitrogen and phosphorus were found in orders 2 and 7. 
After 180 days of planting it was observed that nutrient absorption in orders 3 and 5 increased with increase in the rate of amendment showing that the organic matter has decomposed and hence the nutrient is now available for plant uptake.This is evident in the growth of the oil palm seedlings.

The highest percentage of potassium was found in orders 2 and 7 through-out the planting period, the high concentration of potassium in these orders could be attributed to the higher percentage of fly ash present in these orders. Orders 3 and 5 have the least concentration of potassium due to lower concentration of fly ash in them. Generally there was a gradual increase in the absorption of potassium as the rate of amendment increased from $2-15 \%$.

The plots shown in Figure 1 is the representation of the predicted plant height versus the actual plant height for the various amendments.

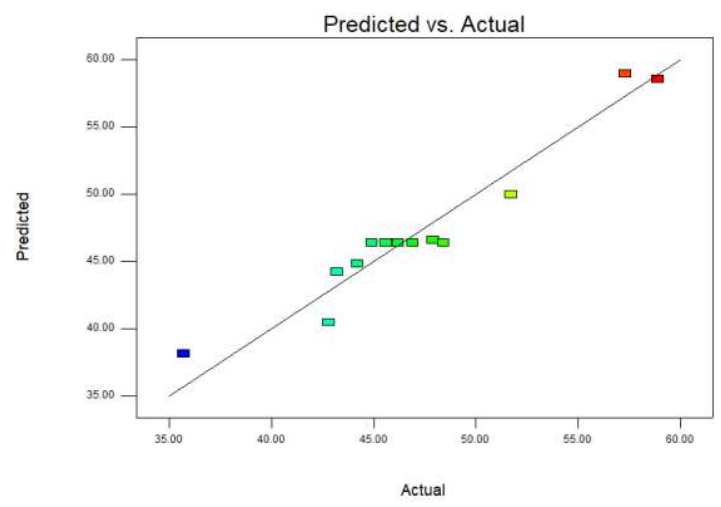

(A)

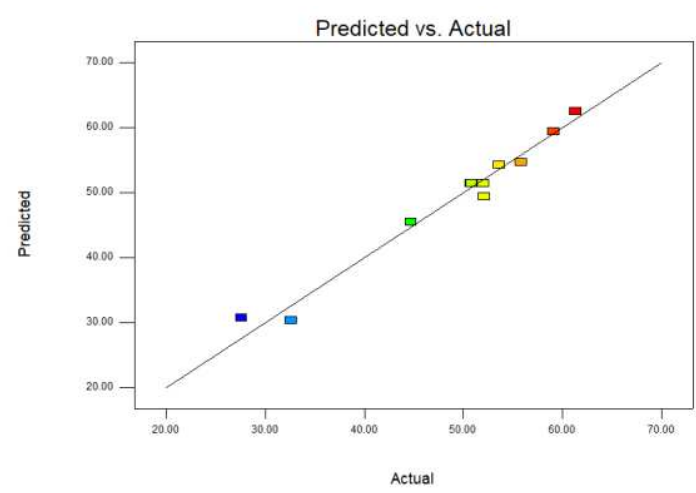

(B) 


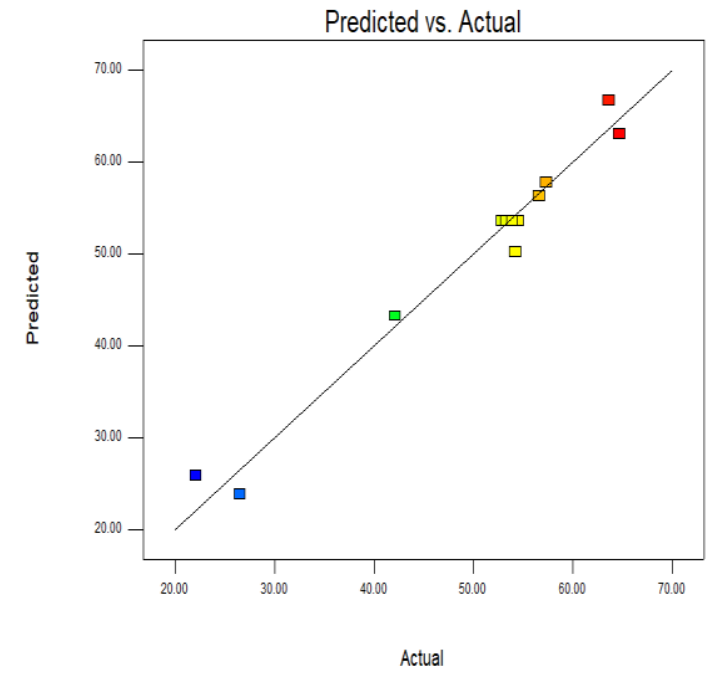

(C)

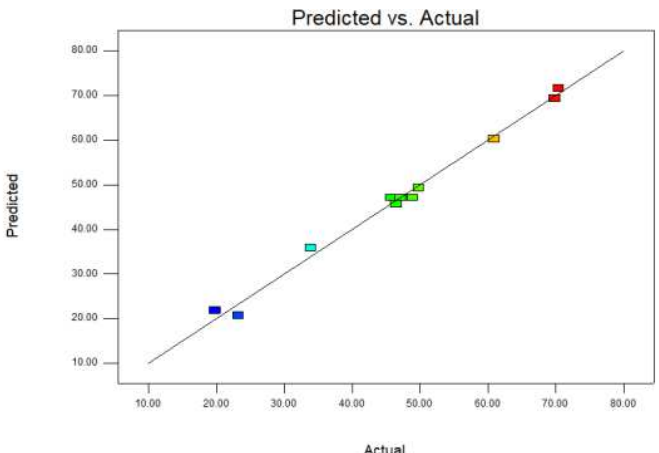

(D)

Figure 1 Predicted vs. Actual Plot for the Various Plant Height (PH)

(A) $2 \%$ soil Amendment (B) $5 \%$ soil Amendment (C) $10 \%$ soil Amendment

\section{(D) $15 \%$ soil Amendment}

Thestrong linear correlation between the predicted and the actual plant height indicates that there is close agreement between the observed and the predicted plant height. This indicates that the model is satisfactory.

Tables 9 -12 shows model summary statistics for the plant height.

Table 9: Model Summary Statistics for Plant Height (A)

Std.

\begin{tabular}{lllllll} 
Source & Dev. & R-Squared & $\begin{array}{l}\text { R- } \\
\text { Squared }\end{array}$ & $\begin{array}{l}\text { R- } \\
\text { Squared }\end{array}$ & PRESS & \\
\hline Linear & 3.2079 & 0.7696 & 0.7235 & 0.5156 & 216.3493 & \\
2FI & 3.1074 & 0.8054 & 0.7406 & 0.4995 & 223.5534 & \\
Quadratic & $\mathbf{1 . 9 8 5 0}$ & $\mathbf{0 . 9 3 8 2}$ & $\mathbf{0 . 8 9 4 1}$ & $\mathbf{0 . 6 5 0 1}$ & $\mathbf{1 5 6 . 2 8 8 1}$ & Suggested \\
Cubic & 1.2721 & 0.9819 & 0.9565 & 0.8443 & 69.5387 & Aliased \\
\hline
\end{tabular}


Table 10: Model Summary Statistics for Plant Height (B)

\begin{tabular}{lllllll}
\hline Source & $\begin{array}{l}\text { Std. } \\
\text { Dev. }\end{array}$ & R-Squared & $\begin{array}{l}\text { Adjusted } \\
\text { R-Squared }\end{array}$ & $\begin{array}{l}\text { Predicted } \\
\text { R-Squared }\end{array}$ & PRESS & \\
\hline Linear & 4.8202 & 0.7892 & 0.7470 & 0.5523 & 493.3704 & \\
2FI & 4.5135 & 0.8336 & 0.7782 & 0.6226 & 415.8845 & \\
Quadratic & $\mathbf{1 . 9 7 8 5}$ & $\mathbf{0 . 9 7 5 1}$ & $\mathbf{0 . 9 5 7 4}$ & $\mathbf{0 . 8 3 0 6}$ & $\mathbf{1 8 6 . 7 1 7 5}$ & Suggested \\
Cubic & 1.3761 & 0.9914 & 0.9794 & 0.5333 & 514.2938 & Aliased \\
\hline
\end{tabular}

Table 11: Model Summary Statistics for Plant Height (C)

Std.

Adjusted Predicted

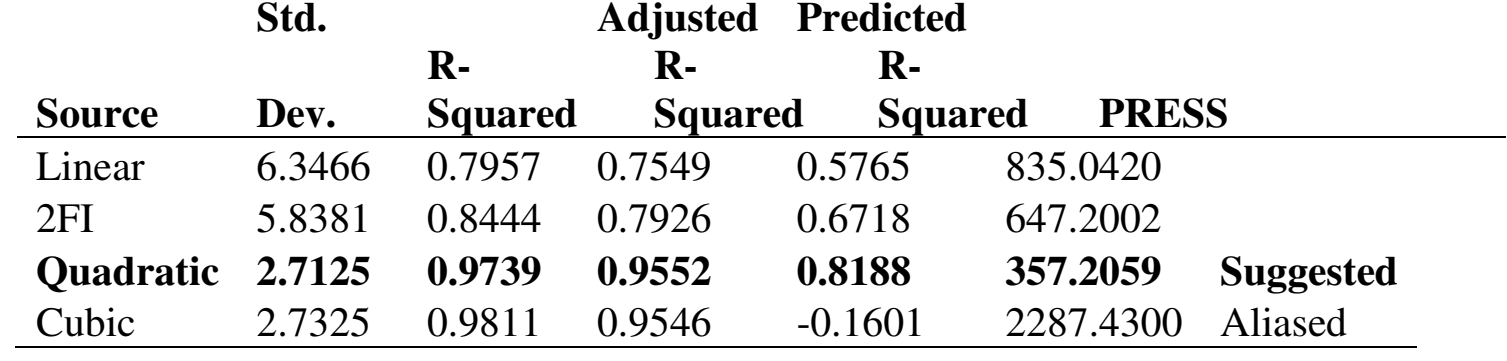

Table 12: Model Summary Statistics of Plant Height (D)

\begin{tabular}{|c|c|c|c|c|c|c|}
\hline Source & $\begin{array}{l}\text { Std. } \\
\text { Dev. }\end{array}$ & $\begin{array}{l}\text { R- } \\
\text { Squared }\end{array}$ & $\begin{array}{l}\text { Adjusted } \\
\text { R- } \\
\text { Squared }\end{array}$ & $\begin{array}{l}\text { Predicted } \\
\text { R- } \\
\text { Squared }\end{array}$ & PRESS & \\
\hline Linear & 3.9696 & 0.9428 & 0.9313 & 0.8761 & 341.1721 & \\
\hline $2 \mathrm{FI}$ & 4.1601 & 0.9434 & 0.9246 & 0.8679 & 363.7466 & \\
\hline Quadratic & 1.8208 & 0.9916 & 0.9855 & 0.9527 & 130.2956 & Suggested \\
\hline Cubic & 1.4171 & 0.9964 & 0.9912 & 0.9085 & 251.7813 & Aliased \\
\hline
\end{tabular}

There is a positive significant correlation between the adjusted R-squared value $(0.8941,0.9574$, 0.9552 and 0.9855$)$ and the predicted R-squared value $(0.650,0.8306,0.8188$ and 0.9527$)$ for amendment $\mathrm{A}, \mathrm{B}, \mathrm{C}$ and $\mathrm{D}$ respectively, (tables $9,10,11$ and 12 respectively) andthe high values show that the model (Equations 3 - 6) reasonably predicted the process using a quadratic polynomial.

The data obtained were subjected to analysis of variance (ANOVA) at a significant level of $5 \%$. The high F-values of 21.2712, 54.9042, 52.1956 and 164.6641 and the very low P-values range of $<0.0001-0.0004$ obtained for amendments A, B, C and D respectively indicated a very significant model. The coefficient of regression $\left(\mathrm{R}^{2}\right)$ was used to validate the fitness of the model equations. High $\mathrm{R}^{2}$ values of $0.9382,0.9751,0.9739$ and 0.9916 obtained for soil amendment A, 
$\mathrm{B}, \mathrm{C}$ and $\mathrm{D}$ (tables $9,10.11$ and 12 respectively) showed that more than $90 \%$ of the variability in the plant height in the soil amendment process can be explained by the model.

Coefficient of variation $(\mathrm{CV})$ in all cases $(<5.5 \%)$ ranged $3.53-5.38 \%$ andis within acceptable range. The small values of $\mathrm{CV}$ gives better reproducibility. Adequate precision measures the signal to noise ratio. A ratio greater than 4 is desirable. The ratio of $15.43,24.003,23.199$ and 41.086obtained for the soil amendments indicate an adequate signal (Russel, 2009). It also shows that the model can be used to navigate the design space.

\subsubsection{Model Deduction}

Equations (3 - 6) give the empirical model of the process, showing the relationship between plant height and the variables considered (mass of FA and POMS) in coded symbols.

$$
\begin{aligned}
& P H_{A}=46.40-5.05 A+4.18 B-2.00 A B+2.49 A^{2}-1.18 B^{2} \\
& P H_{B}=51.38-6.06 A+8.49 B+3.50 A B+1.31 A^{2}-4.34 B^{2} \\
& P H_{C}=53.56-8.28 A+11.30 B+4.90 A B+0.70 A^{2}-5.87 B^{2} \\
& P H_{D}=47.10-11.83 A+13.58 B+0.67 A B+2.72 A^{2}-3.03 B^{2}
\end{aligned}
$$

In equations (3 - 6) above a positive coefficient means that an increase in the variable will cause an increase in the response while a negative coefficient will result in a decrease in the response (Russel, 2009; Ocholiet al. 2018). Hence, an increase in A, AB and $B^{2}$ (which have negative coefficients) lead to decrease in the plant height (2\% soil amendment equation 3 ) while an increase in B and $A^{2}$ (which have positive coefficients) will lead to an increase in plant height (equation 3).

Flyash mass (A) showed the highest effect (coefficient of 5.05) on the plant height at $2 \%$ soil amendment. Equations 4-6 indicate that the POMS mass (B) has the greatest effect on the plant 
height since it has the highest coefficient. An increase in the mass of POMS led to a corresponding increase in the plant height.

From Figures2 - 5(a) the effect of interaction of mass of FA (A) and mass of POMS (B) on the plant height using 3D response surface plot is shown while Figures $2-5$ (b) represents the corresponding contour plots.

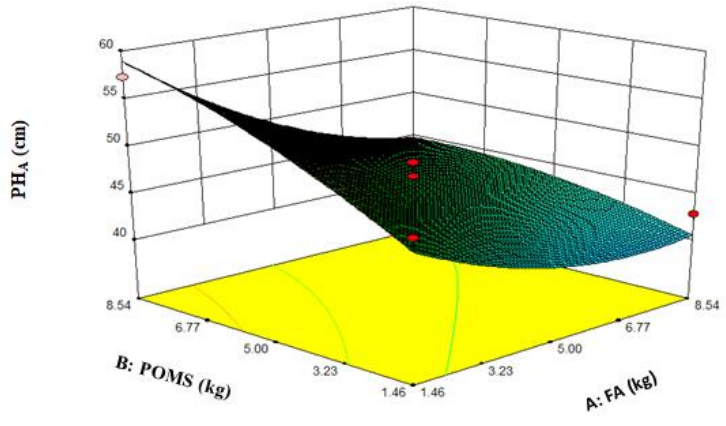

(a)

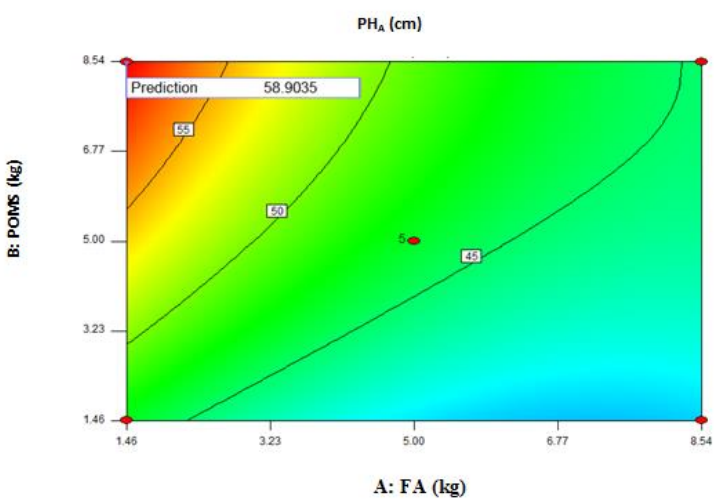

(b)

Figure 2 (a-b): Effect of Interaction of Fly Ash and Sludge on Plant Height (A):

(a) Response Surface Plot and (b) Contour Plot

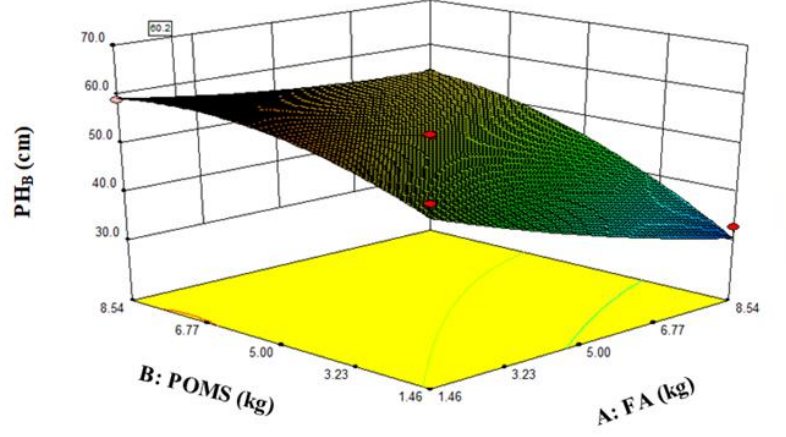

(a)

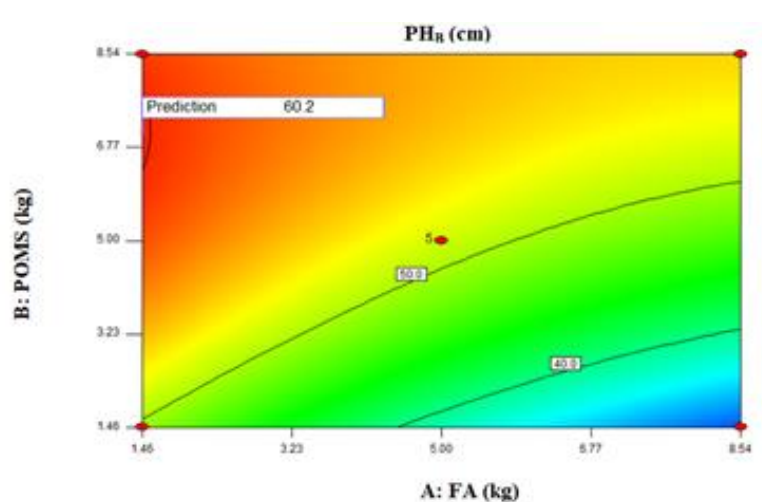

(b)

Figure3 (a-b): Effect of Interaction of Fly Ash and Sludge on Plant Height (A): (a) Response Surface Plot and (b) Contour Plot 


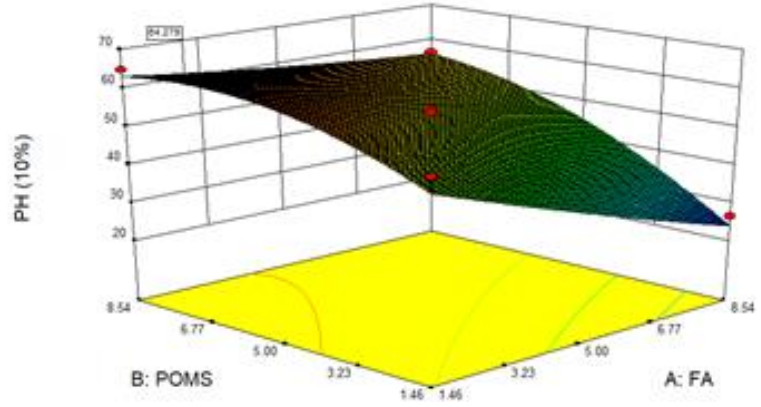

(a)

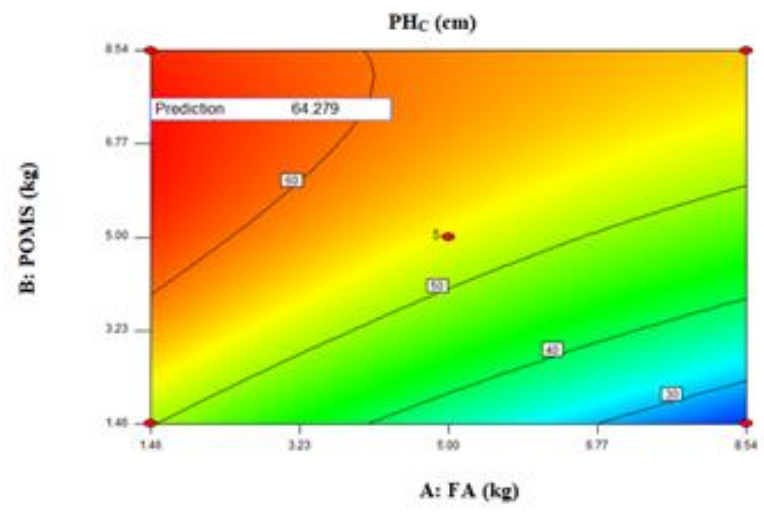

(b)

Figure 4 (a-b): Effect of Interaction of Fly Ash and Sludge on Plant Height (A): (a) Response Surface Plot and (b) Contour Plot

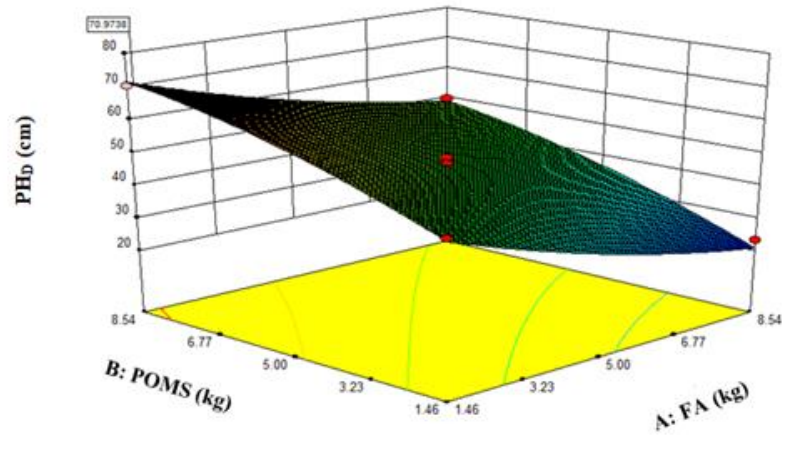

(a)

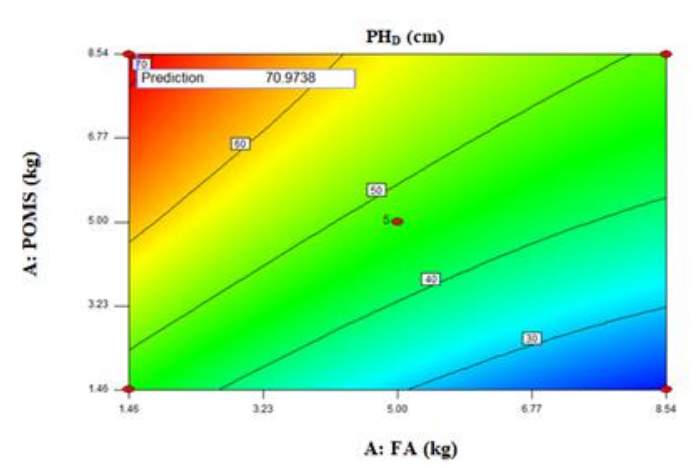

(b)

Figure 5 (a-b): Effect of Interaction of Fly Ash and Sludge on Plant Height (A):

(a) Response Surface Plot and (b) Contour Plot

It was observed from Figures 2 - 5 that the mass of POMS showed more dominant effect on the plant height than the mass of fly ash. The maximum plant heights of58.90, 60.20, 64.28 and $70.97 \mathrm{~cm}$ were observed at a POMS mass of $8.52,7.03,6.93$ and $8.53 \mathrm{~kg}$ and fly ash mass of $1.47,1.46,1.46$ and $1.58 \mathrm{~kg}$ for $2 \%, 5 \%, 10 \%$ and $15 \%$ amendment respectively.

\subsection{CONCLUSION}

This research attempted to assess the effect of optimizing nutrient parameters on the growthof oil palm seedlings in soil amended with fly ash (FA) and palm oil mill sludge (POMS).The optimization of results using RSM showed that an increase in the mass of FA and a decrease in the mass of POMS resulted in a decrease in the growth response of the oil palm seedlings and 
vice versa. The result obtained from the developed empirical quadratic polynomial model showed that strong linear correlation existed between the observed plant responses and predicted responses and thus the model reasonably predicted the process using a quadratic polynomial. The maximum plant height of $70.4 \mathrm{~cm}$ at $15 \%$ soil amendment was obtained at a mass of $1.46 \mathrm{~kg}$ FA and $8.54 \mathrm{~kg}$ POMS for the 180 days planting period.

The data obtain from this research revealed that response surface methodology can be used to optimize nutrient parameters influencing oil palm seedling growth in soil amended with fly ash and sludge and that the co-application of FA and POMS can be very effective at a maximum of $14.6 \%$ FA and minimum of 85.4 \% POMS by mass for planting oil palm seedlings.

\section{ACKNOWNLEDGEMENT}

We are most grateful to the Department of Chemistry University of Benin for providing an enabling environment for the research work.

\section{Funding}

This research did not receive any specific grant from funding agencies in the public, commercial, or not-for-profit sectors,

\section{REFERENCES}

Antoni, S.W., Wijaya, D., Hardjito, K., 2016. Factors affecting the setting time of fly ash-based geopolymer. Mater. Sci. Forum, 841: 90-97

Baudron, F., Jaleta, M., Okitoi, O., Tegegn, A. 2014. Conservation agriculture in African mixed crop-livestock systems: Expanding the niche. Agriculture, Ecosystem and Environment, 187: $171-182$. 
Dercon, S., Christiaensen, L., 2011. Consumption Risk, Technology Adoption, and Poverty Traps: Evidence from Ethiopia. Journal of Development Economics, 96: 159-173.

Devagi, K., Awangku, N., Syafiq, A.M.,Hollena, N., 2016. Uptake of heavy metals from palm oil mill effluent sludge amended soils in water spinach. Journal of Sustainability Science and Management, 11 (1): 113-120.

Food and Agricultural Organisation, 2002. Physical aspects of crop productivity". www.fao.org. (accessed July, 2019)

Kassie, M., Zikhali P., Manjur K., Edwards, S., 2009. Adoption of Organic Farming Techniques: Evidence from a Semi-Arid Region of Ethiopia. Environment for Development Discussion Paper Series, pp. $9-16$.

Kesh, S., Kalra, N., Sharma S.K., Chaudhary, A., 2003. Fly ash incorporation effects on soil characteristics, growth and yield of wheat. Asia Pacific Journal of Environmental Development, 4:53-69.

Motsara, M.R., Roy, R.N., 2008. Guide to laboratory establishment for plant nutrient analysis. Food and Agriculture Organization of the United Nations, 19: 80-122.

Negassa, W., Gebrekidan, H., Friesen, D.K., 2005. Integrated Use of Farm yard Manure and NPK fertilizers for Maize on Farmers' Fields. Journal of Agriculture and Rural Development in the Tropics and Subtropics, 106 (2): 131-141.

Ocholi, O., Menkiti, M., Auta, M, Ezemagu, I., 2018. Optimization of the operating parameters for the extractive synthesis of biolubricant from sesame seed oil via response surface methodology. Egyptian Journal of Petroleum, 27: 265-275. 
Ohimain, E.I., Izah, S.C. 2013. Gaseous emissions from a semi-mechanized oil palm processing mill in Bayelsa state, Nigeria,Continental J. of Water, Air and Soil Pollution, 4 (1): 15 25.

Ohimain, E.I., Izah, S.C., Abah, S.O., 2013. Air quality impacts of smallholder oil palm processing in Nigeria. Journal of Environmental Protection, 4: 83-98.

Ohimain, E.I., Izah, S.C., 2014. Water minimization and optimization by small-scale palm oil mill in Niger Delta, Nigeria. J. of Water Res., 135: 190 - 19.

Osa-Iguehide, I., Okuo, J.M., Anegbe, B., Babalola, B.M., Aigbogun., 2021. Elemental and mineral variation of amended soil for palm seedling growth. J. Chem. Soc. Nigeria, 46 (1): $141-148$

Pathan, S.M, Aylmore, L..A.G., Colmer, T.D. 2003. Soil properties and turf growth on a sandy soil amended with fly ash. Plant Soil, 256: 103-114.

Queensland Department of Environment and Heritage Protection, (2016). Soil pH, www.qld.gov.au. (Accessed 15 August 2019).

Rupani, P.F., Singh, R.P., Ibrahim, H., Esa, N., 2010. Review of current palm oil mill effluent (POME) treatment methods: Vermi-composting as a sustainable practice. World Applied Sciences Journal, 11 (1): 70-8I.

Russell, V.L., 2009. Response surface methods in R, using RSM, J. Stat. Ease Software, Mineapolis, USA.

Singh, R. P., Gupta, A. K., Ibrahim, M. H., Mittal, A. K. 2010. Coal fly ash utilization in agriculture: its potential benefits and risks. Reviews in Environmental Science and Biotechnology, 9 (4), 345-358. 
Singh, R.P., Embrandiri, A., Ibrahim, M.H., Esa, N. 2011. Management of biomass residues generated from oil mill: vermicomposting a sustainable option. Resource Conservation, 55: 423-434.

Surridge A.K.J, Merwe, A., Kruger, R., 2009. Preliminary microbial studies on the impact of plants and South African fly ash on amelioration of crude oil polluted soils. In World of Coal Ash (WOCA) conference, May 4-7.

United States Department of Agriculture, 2000. Oil Palm Production, Consumption, Exports and Imports Statistics.

Valbuena, D., Tui, S.H., Erenstein, O., Teufel, N., Duncan, A., Abdoulaye, T., Swain, B., Mekonen, K., Germaine, I., Gérard, B., 2015. Identifying determinants, pressures and trade-offs of crop residue use in mixed smallholder farms in Sub-Saharan Africa and South Asia. Agricultural Systems, 134: 107-118.

Vogel, M., 2008. Text Book of quantitative Chemical Analysis. Prentice Hall, England.

Wuana, R. A., Okieimen F. E., Imborvungu, J.A., 2010. Removal of heavy metals from a contaminated soil using organic chelating acids. International Journal of Environmental Science and Technology, 7 (3): 485-496. 